\title{
Penerapan Pembelajaran Kooperatif Melalui Model Group Investigation Untuk Meningkatkan Literasi Ekonomi Siswa
}

\author{
Dadang Saepuloh ${ }^{1}$, Siti Rodiah ${ }^{2}$ \\ ${ }^{1,2}$ Economic Education Program, Universitas Islam Syekh-Yusuf Tangerang, Indonesia \\ dsaepuloh@unis.ac.id, sitirodiah9797@gmail.com
}

\begin{abstract}
This research was motivated by the problems in the low economic literacy of students in economic subjects are supported by still lack of economic literacy of students based on the results of observations. This research aims to reveal the differences in increasing economic literacy of students before being given treatment and after treatment is given through a learning model of Group Investigation (GI) experimental class and conventional learning (lectures) control class. This research is a quantitative research using Quasi Experimental Design. Economic literacy data obtained from the post-test students in the form of essays. These results indicate that there is a difference between economic literacy of students who applied to the learning model group investigation with the economic literacy of students who applied to conventional models. Based on the research results mengguankan t-test. This matterit can be concluded that the Group Investigation learning model can improve economic literacy.

Keywords: Cooperative Learning Model Group Investigation (GI), Economic Literacy.
\end{abstract}

History of Article:

Received: (01-11-2019), Accepted : (15-12-2019), Publised: (24-03-2020)

\section{Citation:}

Saepuloh, D \& Rodiah, S (2020) Penerapan Pembelajaran Kooperatif Melalui Model Group Investigation Untuk Meningkatkan Literasi Ekonomi Siswa, Jurnal Pendidikan Ekonomi, 13(1), $30-41$

(C) Universitas Negeri Malang 
PENDAHULUAN

Kehidupan manusia tidak pernah terlepas dari kegiatan ekonomi yang mengkaitkan antara konsep ilmu ekonomi dengan kegiatan ekonomi pada tataran praktiknya (Iis aisyah, 2014), literasi ekonomi atau secara sederhana diistilahkan sebagai "melek ekonomi" merupakan kemampuan mengidentifkasi masalah-masalah ekonomi, penyusunan alternative pemecahan dengan mempertimbangkan keuntungan dan biaya (Utomo, 2018). Senada dengan yang diutarakan (Nurul Lailiya, 2019) bahwa Literasi ekonomi merupakan suatu pemahaman seseorang dalam menentukan keputusan ekonomi dalam sehari-hari serta mampu dalam membantu seseorang untuk membedakan kebutuhan dan keinginan.

Di era teknologi yang semakin canggih pada saat ini membutuhkan manusiamanusia ekonomi cerdas yang mampu menghasilkan pendapatan untuk dirinya, menentukan keputusan yang terbaik di waktu yang tepat, dan meningkatkan kesejahteraan hidup yang dijalani. (Saepuloh, 2019.) mengungkapkan bahwa Prestasi belajar Ekonomi merupakan salah satu indikator yang dapat dipakai untuk mengetahui keberhasilan belajar untuk diaplikasikan ilmunya dalam kehidupan sehari-hari. Seperti yang diutarakan Mathews (1999) bahwa melek ekonomi sebagai potensi seseorang untuk mengenal dan mengaplikasikan konsep-konsep ekonomi dan kemampuan berpikir secara ekonomi untuk memperbaiki dan mendapatkan kesejahteraan bagi hidupnya. Hal ini sesuai dengan hasil penelitian Imawati dkk, 2013 (Kumalasari \& Soesilo, 2019) yang menyatakan bahwa dalam pengelolaan ekonomi yang benar, akan ditinjau oleh literasi ekonomi yang baik, maka taraf kehidupan seseorang akan meningkat. Pembangunan budaya literasi pada masyarakat indonesia saat ini masih didominasi dari nilai-nilai patriarch yang bersifat top down dan sangat kurang dalam pendekatan kulturalnya. Sudah sejak lama disadari bahwa budaya literasi pada masyarakat indonesia saat ini masih sangat jauh dari negara-negara lain. Bahkan dibanding dengan beberapa negara-negara tetangga di Asia Tenggara, Indonesia berada pada tingkat terendah capaian literasinya (Lukito, n.d.) Media Indonesia, Kamis, 07 Februari 2019

Literasi ekonomi bermanfaat untuk pelajar, karena digunakan sebagai bekal ketika para pelajar menjadi dewasa (bekal pada masa yang akan datang), dan untuk kehidupan sehari-hari (Hambali, 2016). Literasi ekonomi sangat penting dalam kehidupan siswa karena literasi ekonomi dapat menghadapi masalah-masalah ekonomi yang relevan dengan kehidupan ekonomi mereka (Lilik Ernawati, 2017). Karena semakin baik tingkat literasi siswa maka akan semakin baik pula tingkat daya serap peserta didik di kelas dalam mengeksplorasi ilmu pengetahuan (Muhammad Andri Utama; Dwi Atmono, 2016).

Guru dan pendidik mempunyai peran yang besar dalam menanamkan kemampuan dasar literasi sejak dini bagi para peserta didik, yang pada akhirnya tingkat literasi masyarakatpun dapat semakin meningkat (lukito media Indonesia). Literasi merupakan ciri utama yang penting dari perilaku ekonomi di dalamnya mengemukakan konsep yang banyak dipelajari, dan menjelaskan inti dari memahami mengenai perilaku ekonomi dalam masyarakat modern (Amalia Di Girolamo, Glenn W. Harrison, 2015)

Berdasarkan hasil penelitian PISA (2012) Programme for International Student Assessment mengungkapkan bahwa, literasi pada masyarakat Indonesia di tahun 2012 menjadi terburuk kedua dari 66 negara yang diteliti di dunia. Indonesia menempati urutan ke 65 dari 66 negara tersebut. Hal ini menunjukkan bahwa kemampuan literasi siswa masih sangat rendah. Ditambahkan dengan hasil wawancara yang dilakukan penulis dengan beberapa siswa di SMAN 5 Kabupaten Tangerang mengemukakan bahwa tingkat literasi ekonomi peserta didik masih tergolong rendah dan jauh dari harapan yang ada. hal ini 
dilihat dari pertanyaan-pertanyaan yang dilakukan oleh penulis, seperti masih kurangnya pemahaman siswa tentang pengelolaan pendapatan individu, masih banyaknya siswa yang berbelanja untuk kesenangan pribadi, dan kurangnya pemahaman siswa dalam memaksimalkan sumber daya yang terbatas disekolah.

Rendahnya literasi ekonomi tersebut merupakan masalah mendasar yang memiliki dampak sangat luas bagi kemajuan bangsa. Dalam rangka mendorong masyarakat melek ekonomi, perlu untuk menggabungkan sistem pemikiran ke dalam pengalaman belajar anak-anak, remaja, dan orang dewasa karena merupakan pusat dari pemahaman didasarkan dari isu-isu ekonomi (Reber, 2010). Keberhasilan dalam pembelajaran dapat ditingkatkan jika proses pembelajaran tersebut dapat berlangsung dengan tersedianya sarana dan prasarana yang mendukung dan kemampuan guru dalam mengelola kelas dengan menggunakan metode yang tepat, strategi atau model yang sesuai (Martaida, 2017). Berdasarkan dari penjelasan tersebut, diperlukan adanya pembaharuan atau inovasi untuk mencapai tujuan pembelajaran yang lebih baik. Ilmu dalam pembelajaran harus lebih bervariasi baik pada model pembelajaran, metode dan strategi untuk menciptakan pembelajaran yang aktif, inovatif, kreatif, efektif serta menyenangkan sehingga kemampuan siswa menjadi optimal.

Pendidikan ekonomi yang disediakan oleh sekolah adalah penting karena mempersiapkan siswa untuk mengambil keputusan berbasis ekonomi dalam kehidupan pribadi mereka dan juga dalam kehidupan sosial mereka sebagai warga negara, siswa perlu memahami dan menggunakan dengan benar tentang konsep dasar ekonomi untuk membuat keputusan ekonomi yang rasional di dunia yang kompleks dan terus berubah saat ini (Akhan, 2015). Pelajaran yang berkaitan erat adalah ekonomi. Ekonomi merupakan salah satu mata pelajaran di SMA yang diharapkan mampu untuk memberikan bekal kepada siswa agar dapat memiliki kecakapan dalam bidang ekonomi sehingga siswa akan mampu menjadi pelaku ekonomi yang rasional. Sebagaimana diungkapkan oleh (Haryono, 2013) bahwa mata pelajaran ekonomi memiliki peran yang sangat penting dalam kecakapan dan membentuk sikap yang rasional, terutama dalam pengambilan keputusan ekonomi, siswa yang mampu berpikir dan bersikap rasional dalam melakukan kegiatan ekonomi dapat dikatakan bahwa siswa tersebut telah memiliki literasiekonomi. Di tambahkan oleh (Bayu permata, Hari Wahyono, 2016) Pentingnya materi literasiekonomi diberikan pada anak usiadini dikarenakan dalam kehidupan sehari-hari sebagian aktifitas yang dilakukan seseorang hampir tidak lepas dari ilmu ekonomi. Siswa yang memiliki kemampuan literasi ekonomi cukup baik, dapat berperan serta memberi masukan, menyebarluaskan pengetahuan-pengetahuan ekonomi untuk ikut dalam mempengaruhi perilaku keluarga maupun lingkungan sekitar dimana mereka tinggal (Hambali, 2016).

Permasalahan mengenai rendah nya literasi ekonomi dalam pendidikan Indonesia pun terjadi di SMAN 5 Kabupaten Tangerang, para siswa di SMAN 5 kabupaten Tangerang ini memiliki kecenderungan yang kurang dalam tingkat literasi ekonomi. Hal ini dapat dilihat dari hasil penyebaran lembar observasi tentang literasi ekonomi dalam bentuk diagram dibawah ini. 


\section{Gambar 1.1 ObservasiTingkat Literasi Ekonomi}

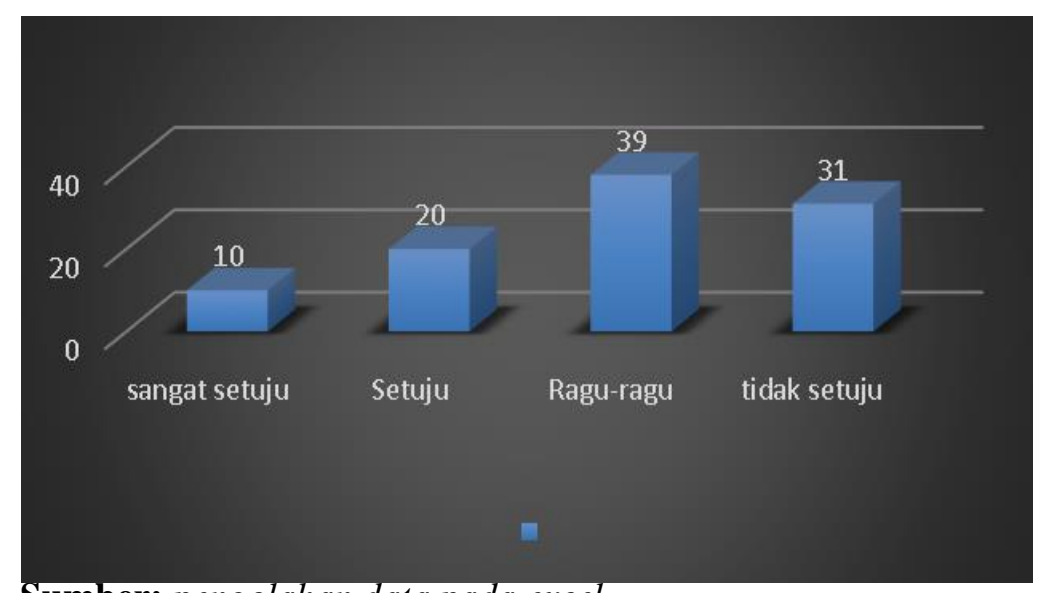

Sumber: pengolahan data pada excel

Dari diagram di atas dapat dilihat bahwa banyaknya siswa yang memilih "Sangat Setuju" sebesar 10\% sedangkan yang melilih "Setuju"sebesar 20\% kemudian yang memilih "Ragu-ragu'sebesar 39\% dan yang terakhir "Tidak Setuju”' sebesar 31\%. Dalam lembar observasi literasi ekonomi, ini membuktikan bahwa siswa SMAN 5 Kabupaten Tangerang masih kurangnya tingkat literasi ekonomi dalam mata pelajaran ekonomi sekolah menengah atas karena banyaknya siswa yang memilih jawaban "Ragu-ragu" yaitu sebesar 39\%. Hal ini merupakan permasalahan penting dalam pendidikan. Maka dari itu perlu adanya penerapan model pembelajaran yang dapat meningkatkan literasi ekonomi siswa.

Kualitas suatu bangsa ditentukan oleh pengetahuan dan kecerdasannya, sedangkan pengetahuan dan kecerdasan di hasilkan oleh seberapa besar ilmu pengetahuan yang telah didapatkan, sedangkan ilmu pengetahuan di dapat dari informasi yang diperoleh melalui lisan maupun tulisan. Semakin banyak penduduk di wilayah yang semangat dalam mencari ilmu pengetahuan, maka akan semakin tinggi pula peradabannya (Ane Permatasari, 2015)

Rendahnya kemampuan literasi siswa bisa jadi dikarenakan pembelajaran yang masih bersifat monoton, siswa hanya mendengarakan dan mencatat tentang apa yang dijelaskan oleh guru, sementara guru tidak memberikan kesempatan kepada siswa untuk mengkonstruksi dan mengembangkan pengetahuannya sendiri melalui diskusi dan kerja sama (Sai, 2017). Upaya dalam menanggapi masalah yang timbul tersebut maka hal yang dapat dilakukan yaitu dengan memperbaiki atau memberikan pembaharuan terhadap model pembelajaran yang efektif untuk dterapkan pada proses pembelajaran tersebut, karena model pembelajaran juga merupakan faktor pendukung dari keberhasilan siswa dalam belajar (Chera Rizqi Faujiyah, Idad Suhada, 2017).

Pada materi ekonomi dalam konteks pembelajaran dapat dikatakan berhasil apabila peserta didik memiliki kemampuan tingkat literasi ekonomi yang baik (Utomo, 2018). Munculnya peningkatan kemampuan literasi juga dapat dilihat melalui penerapan tipe pembelajaran kooperatif dengan berbagai varian-variannya, karena model pembelajaran kooperatif ini membagi siswa dalam kelompok-kelompok kecil untuk dapat bekerja sama (Sai, 2017), Model pembelajaran kooperatif Group Investigation merupakan model yang di kembangkanuntuk kreativitas siswa, baik perseorangan maupun kelompok, serta siswa 
dapat mempersiapkan sendiri materi yang ingin dipelajari, hal tesebut sejalan dengan pendapat Sapir 2013 (Astuti \& Agung Haryono, 2017), Dengan menerapkan suatu model pembelajaran yang dapat melibatkan siswa aktif dalam pembelajaran salah satunya yaitu dengan Model pembelajaran group investigation yang dapat memberikan kesempatan seluas-luasnya kepada siswa untuk terlibat langsung dan aktif dalam proses pembelajaran Sharan and Sharan (1990).

Pembelajaran kooperatif merupakan salah satu model pembelajaran yang dianjurkan untuk digunakan dalam proses pembelajaran pada kurikulum 2013, Selain dapat digunakan untuk mengembangkan pesertadidik, metode pembelajaran ini mendorong siswa untuk bekerja sama, mencari solusi atau menciptakan produk dengan membuat upaya intelektual bersamadan interaksi social (kim et al, 2008). Ditambakan oleh Sumanik Magdalena (2015) bahwa model Group Investigation merupakan suatu proses pembelajaran yang bersifat kooperatif atau kelompok dimana pesertadidik akan berusaha untuk menemukan suatu informasi (gagasan, opini, data solusi) dan lain sebagainya yang berkaitan dengan pembelajaran dari berbagai sumber pendukung yang terkait, dimana pada akhirnya siswa akan berusaha untuk mengevaluasi dan mensintesis kebenaran informasi yang telah diperoleh secara bersama, dimana pada model pembelajaran ini peserta didik diharapkan mampu berfikir mandiri, dan mengembangkan kemampuan sosialemosionalnya dalam bekerja berkelompok.

Model pembelajaran group investigation merupakan bentuk dari salah satu pembelajaran kooperatif yang menekankan kepada siswa untuk dapat mencari sendiri mengenai tema/sub pokok materi (informasi) suatu pelajaran yang akan dipelajari melalui bahan-bahan atau materi yang sudah tersedia, contohnya dari buku pelajaran atau siswa dapat mencari melalui internet ataupun perpustakaan (Sai, 2017). Penerapan model pembelajaran Group Investigation dapat memberikan stimulus terhadap siswa untuk dapat terlibat aktif dalam proses pembelajaran, hal ini disebabkan karena dalam penerapan pembelajarannya, siswa akan belajar secara mandiri dalam bentuk kelompok untuk menginvestigasi atau menyelidiki, mencari, menemukan, dan menganalisis informasi dari berbagai sumber mengenai materi pembelajaran yang telah dibagikan kepada masingmasing kelompok Takaeb and Mone (2018). Dengan pembelajaran kooperatif, siswa tidakhanya mampu meningkatkan literasi ekoomi siswa dengan menyediakan kesempatan bagi siswa untuk belajar bagaimana para profesional di berbagai bidang bekerja sama dalam berbagai industri, namun siswa juga mengalami suatu peristiwa sukses dalam psikologi dan ilmu pendidikan karena mampu menghasilkan prestasi akademik, sikap, serta perilaku yang lebih baik.R. M. Gillies A. F. Ashman J. Terwel (2008).

Berdasarkan uraian di atas maka penulis tertarik melakukan penelitian "Penerapan Pembelajaran Kooperatif Melalui Model Group Investigation Untuk Meningkatkan Literasi Ekonomi Siswa Kelas X di SMA Negeri 5 Kabupaten Tangerang (Studi Kasus Pada Materi Koperasi)".

\section{METODE}

Jenis penelitian yang digunakan adalah penelitian kuantitatif. Metode yang digunakan adalah metode Quasi Eksperimental Design. Alasan desain kuasi-eksperimental bukan eksperimen yang benar berkaitan dengan fakta bahwa mereka tidak terjadi di lingkungan yang sepenuhnya dikendalikan (Tharenou, P., Donohue, R., 2017). Penelitian ini dilaksanakan di SMAN 5 Kabupaten Tangerang dalam mata pelajaran ekonomi studi kasus pada materi koperasi. Populasi merupakan sekelompok individu yang memiliki ciri-ciri khusus yang sama(Cresswell, 2015). Populasi dalam penelitian ini adalah kelas X IPS 
SMA Negeri 5 Kabupaten Tangerang yang terdiri dari 5 kelas berjumlah 179 siswa. Sampel merupakan sub kelompok dari populasi target yang direncanakan diteliti untuk menggeneralisasikan tentang populasi target (Cresswell, 2015). Penentuan ukuran sampel dari populasi menggunakan teknik convenience sampling dimana penulis memilih partisipan karena mereka mau dan bersedia di teliti maka didapat sampel sebanyak 70 siswa. Adapun teknik yang digunakan untuk mengumpulkan data adalah tes, pengamatan (observasi), dan dokumentasi. Teknik pengumpulan data yang digunakan oleh peneliti adalah uji validitas dan reliabilitas yaitu untuk mendapatkan fakta yang ada dilapangan secara akurat.Validitas merupakan suatu ukuran yang menunjukan tingkat keaslian atau kebenaran suatu instrument (Arikunto 2017). Uji validitas yang dilakukan setelah melakukan uji instrumen, didapatkan dari 10 soal essay dinyatakan 8 soal valid, dan 2 soal tidak valid. Nilai reliabilitas yang dapat dari nilai alpha yaitu sebesar 0,618 >0,329 ( $\mathrm{r}$ tabel) yang menunjukan bahwa soal instrument tingkat literasi ekonomi dikatakan reliabel dan mempunyai tingkat reliabel yang cukup.

Untuk mengetahui ada tidaknya perbedaan antara data-data yang dibandingkan, yaitu literasi ekonomi kelas eksperimen dan kelas kontrol yang dianalisis menggunakan analisis statistik dengan taraf signifikan $\alpha=0,05$. Independent sempel T Test atau uji beda dua rata-rata yang digunakan untuk menguji dua rata-rata dari dua kelompok independen.

\section{HASIL DAN PEMBAHASAN}

Penelitian ini memberikan deskripsi tentang rangkuman hasil penelitian sehingga dapat membuat kesimpulan dalam pengolahan data. Adapun hasil pengolahan data tersebut dapat dilihat pada tabel berikut ini.

Tabel 1 Deskripsi Data Pretest dan Posttest Kelas Eksperimen

\begin{tabular}{lccccc}
\hline & N & Minimum & Maximum & Mean & $\begin{array}{c}\text { Std. } \\
\text { Deviation }\end{array}$ \\
\hline $\begin{array}{l}\text { Prestest Eksperimen } \\
\text { Posttsest }\end{array}$ & 34 & 30 & 53 & 40,35 & 4,773 \\
Eksperimen & 34 & 56 & 98 & 79,97 & 7,129 \\
Nilai Beda & 34 & 25 & 58 & 39,62 & 8,202 \\
Valid N (Listwise) & 34 & & & & \\
\hline
\end{tabular}

Sumber: Hasil pengolahan data SPSS dengan menggunakan SPSS 25

Berdasarkan deskripsi tabel pretest dan posttest kelas eksperimen di atas dapat dilihat mean yang merupakan nilai rata-rata kelas eksperimen memperoleh nilai sebesar 79,97. Sedangkan untuk nilai kelas eksperimen dalam kegiatan pembelajaran hasilnya menunjukan bahwa nilai terendah $(\min )$ adalah 65 sampai nilai tertinggi (max) adalah 98 dengan rentang nilai sebesar 33 dengan standar devisiasi 7,129.

Tabel 2 Deskripsi Data Prestest dan Posttest Kelas Kontrol

\begin{tabular}{lccccc}
\hline & N & Minimum & Maximum & Mean & $\begin{array}{c}\text { Std. } \\
\text { Deviation }\end{array}$ \\
\hline Prestest Kontrol & 34 & 30 & 48 & 39,53 & 4,968 \\
Posttest Kontrol & 34 & 55 & 85 & 69,47 & 7,641 \\
Nilai Beda & 34 & 12 & 50 & 29,94 & 9,804
\end{tabular}


Valid N (Listwise)

34

Sumber: Hasil pengolahan data SPSS dengan menggunakan SPSS 25

Berdasarkan tabel deskripsi data pretest dan posttest kelas kontrol diatas dapat dilihat mean yang merupakan nilai rata-rata kelas kontrol memperoleh nilai sebesar 69.47. sedangkan untuk nilai kelas eksperimen dalam kegiatan pembelajaran hasilnya menunjukan bahwa nilai terendah ( $\min )$ adalah 55 sampai nilai tertinggi (max) adalah 85 dengan rentang nilai sebesar 30 dengan standar devisiasi 7,641.

Gambar 1. Penelitian ini memiliki tujuan membandingkan dua nilai selisih dari posttest dan pretest antara kelas eskperimen dengan menggunakan model group investigation (GI) dan kelas kontrol konvensional. Apakah antara dua nilai tes tersebut ada perbedaan atau tidak. Pengujian untuk melihat perbedaan ini hanya dilakukan terhadap rata-rata dari dua nilai saja maka digunakan uji-t (t-test).

Tabel 3 HasilUji Hipotesis

$\begin{array}{cc}\text { Levene's Test For } & \text { T-Test For Equality } \\ \text { Eguality Of Variances } & \text { Of Means }\end{array}$

\begin{tabular}{lcccc} 
& $\mathrm{F}$ & $\mathrm{Sig}$ & $\mathrm{T}$ & $\mathrm{Df}$ \\
\hline Equal Variances & & & & \\
Assumed & 1,254 & 0,267 & 4,414 & 66 \\
$\begin{array}{l}\text { Equal Variances } \\
\text { Not Assumed }\end{array}$ & & 4,414 & 64,005 \\
\hline \multicolumn{5}{l}{ Sumber: Hasil pengolahan data SPSS dengan menggunakan SPSS 25 }
\end{tabular}

Berdasarkan hasil uji hipotesis data yang diperoleh dapat dilihat nilai $t_{\text {hitung }}$ sebesar 4, 414. Tabel distribusi t dicari $a=5 \%$ atau 0,05 (uji dua sisi). Nilai $t_{\text {tabel }}$ dilihat pada tabel uji-t dua sisi dengan df 66 yaitu sebesar 1,997. Nilai $t_{\text {hitung }}>\mathrm{t}_{\text {tabel }} \quad(4,414$ $>1,997)$, sehingga $\mathrm{H}_{\mathrm{o}}$ ditolak. Jadi dapat disimpulkan bahwa ada perbedaan rata-rata literasi ekonomi siswa dikelas eksperimen dengan kelas kontrol. Yang berarti penerapan model pembelajaran Group Investigation mempunyai pengaruh positif secara signifikan terhadap literasi ekonomi siswa.

Jadi dapat disimpulkan bahwa ada perbedaan antara literasi ekonoimi siswa dikelas eksperimen dan literasi ekonomi dikelas kontrol. Hal ini menunjukan bahwa kelas eksperimen memiliki literasi ekonomi yang lebih tinggi karena menggunakan model pembelajaran Group Investigation dibandingkan dengan kelas kontrol yang menggunakan pembelajaran konvensional (ceramah).

\section{Penerapan Model Pembelajaran Group Investigation Dalam Meningkatkan Literasi Ekonomi Siswa}

Menurut (Matroji, 2015) Pembelajaran Group Investigation(GI) merupakan salah satu model pembelajaran yang diterapkan untuk mencapai tiga tujuan instruksional, yaitu peningkatan prestasi akademik, penerimaan akan perbedaan, serta dalam mengembangkan kepekaan sosial anak dengan harapan agar dapat meningkatkan keaktifan dan hasil pembelajaran siswa. 
Pelaksaan model pembelajaran Group Investigation yang terdiri dari enam langkah yaitu: tahap mengidentifikasi topik, perencanaan tugas yang akan dipelajari, pelaksaan investigation, persiapan laporan akhir, presentasi laporan akhir, dan evaluasi. Sebagaimana yang diutarakan oleh Nur (2014) bahwa model pembelajaran Group Investigation (GI) merupakan salahsatu tipe pembelajaran kooperatif yang mudah diterapkan, melibatkan aktivitas seluruh siswa tanpa harus ada perbedaan status, melibatkan peran siswa sebagai tutor sebaya dan mengandung unsur penguatan. Dalam pelaksaan model pembelajaran Group Investigation para siswa dibagi dalam tim belajar yang terdiri atas lima sampai enam orang yang berbeda-beda tingkat kemampuan, jenis kelamin, dan latar belakang etniknya. Guru memberikan permasalahan yang harus dipelajari, lalu siswa bekerja sama dalam tim mereka. Langkah-langkah dalam model pembelajaran group investigation ini adalah kegiatan awal guru membuka pelajaran dengan salam serta Guru memeriksa kehadiran siswa dan menanyakan kepada peserta didik kesiapan diri untuk mengikuti pembelajaran dan memberikan motivasi agar peserta didik siap untuk belajar. Kemudian Guru menjelaskan materi tentang perkoperasian dalam perekonomian di indonesia.

Guru menyajikan masalah koperasi di indonesia dan peserta didik memperhatikannya. Kemudian siswa membentuk kelompok investigasi yang sudah ditentukan serta merencanakan apa yang akan dipelajari. Siswa diberikan suatu masalah koperasi yaitu masalah tentang kegagalan koperasi di Indonesia. Setelah itu Peserta didik mengidentifikasi hal-hal yang berhubungan dengan permasalahan koperasi melalui pertanyaan-pertanyaan antara lain (berpakah jumlah koperasi yang gagal, Koperasi apa saja yang mengalami kegagalan, Apa saja faktor-faktor yang menyebabkan koperasi gulung tikar/gagal, Bagaimana cara atau solusi dalam menyelesaikan masalah kegagalan koperasi tersebut). Kemudian siswa saling bertukar, berdiskusi, mengklarifikasi dan mempersatukan ide dan pendapat. Masing-masing anggota kelompok mencari solusi untuk menyelesaikan masalahan tentang kegagalan koperasi di Indonesia. Selanjutnya anggota kelompok merencanakan apa yang akan mereka laporkandan bagaimana mempresentasikannya, Perwakilan kelompok mempresentasikan hasil diskusi kelas dalam presentasi investigasi. Kemudian guru dansiswa mengkolaborasi, mengevaluasi tentang pembelajaran yang telah dilaksanakan serta membuat kesimpulan tentang topik permasalahnnya.

Kegiatan akhir Guru memberikan apresiasi terhadap diskusi yang sudah dilakukan, khususnya kepada kelompok yang sudah presentasi dan peserta didik yang aktif dalam diskusi dan guru melakukan evaluasi serta membuat kesimpulan karena menurut Slavin RE(Nur, 2014) bahwa untuk memastikan semua anggota tim telah menguasai pelajaran, yaitu perlu diadakan evaluasi pada tahapan akhir pembelajaran. Kemudian Guru mengakhiri kegiatan pembelajaran dan mengucapkan salam.

Menurut (Indrawati, 2018) Model pembelajaran kooperatif tipe Group Investivigation (GI)dapat melatih siswa untuk menumbuhkan kemampuan berfikir mandiri, dimana siswa terlibat secara aktif mulai dari tahap pertama sampai tahap akhir pembelajaran. Secara singkat kelebihan Group Investigation dapat memberi peluang kepada siswa untuk lebih mempertajam gagasan dan guru akan mengetahui kemungkinan gagasan siswa yang salah sehingga guru dapat memperbaiki kesalahan tersebut Pada proses pembelajaran dengan penerapan model pembelajaran group investigation ini dapat dilaksanakan dengan baik, hal ini dapat dilihat dari penilaian guru mata pelajaran ekonomi (guru pamong) dengan mendapatkan nilai total dari observasi sebesar 78 dengan predikat baik. 


\section{Literasi Ekonomi Siswa dengan Penerapan Model Pembelajaran Group Investigation}

(GI)

Model pembelajaran group investigation di terapkan pada kelas eksperimen yaitu X IPS 3. Siswa pada saat proses pembelajaran menjadi lebih aktif serta dapat menyelesaikan permasalahan koperasi dengan baik. Hasil penilaian siswa pada kelas eksperimen setelah di berikan treatment dengan model pembelajaran group investigation pada mata materi perkoperasian dalam perekonomian di indonesia ini memperoleh data nilai posttest terendah yang diperoleh siswa adalah sebesar 65 sedangkan nilai posttest terbesar adalah 98. Siswa banyak yang memperoleh nilai antara 75-90 hal ini karena siswa dalam menjawab soal posttest sudah mampu memahami dan menjawab soal dengan baik dan benar. Nilai rata-rata posttest kelas eskperimen memperoleh nilai sebesar 79,97.

Penelitian ini sesuai dengan penelitian terdahulu yang di lakukan oleh Azizah Fauziyah (2017) yang hasil penelitiannya menyebutkan bahwa penerapan model pembelajaran Group Investigation cukup efektif dalam meningkatkan literasi keuangan siswa pada mata pelajaran akuntansi di kelas XI IPS 1 SMK Negeri 1 Bandung pada pokok bahasan prosedur peredaran uang karena siswa dapat berinteraksi antar teman sebaya, mempunyai tujuan dan cara alternative dalam menyelesaikan suatu masalah serta aktif dalam kelompok pembelajaran.

Menurut Wina Sanjaya yang menyatakan bahwa pada pembelajaran konvensional siswa ditempatkan sebagai obyek belajar yangberperan sebagai penerima informasisecara pasif (Ibrahim 2017). Jadi pada umumnya penyampaian pelajaran menggunakan metode ceramah, tanya jawab dan penugasan. Pada model pembelajaran konvensional (ceramah) di terapkan pada kelas kontrol yaitu X IPS 4. Pada saat proses pembelajaran siswa kurang memahami materi pembelajaran. Karena proses pembelajaran menggunakan metode ceramah sehingga siswa hanya memperhatikan guru dan siswa menjadi cepat bosan. Dalam proses pembelajaran siswa lebih banyak diam sehingga yang aktif adalah guru bukan siswa. Hasil penilaian siswa kelas kontrol pada mata materi perkoperasian dalam perekonomian di indonesia ini memperoleh nilai posttest terendah sebesar 55, dan nilai posttest tertinggi sebesar 85 . Siswa banyak yang memperoleh nilai antara 60-75 hal ini karena sebagian besar siswa belum mampu dalam menjawab soal posttest dengan baik dan benar. Nilai rata-rata posttest kelas kontrol memperoleh nilai sebesar 69,47.

Berdasarkan penjelasan di atas dapat dilihat bahwa hasil penelitian menunjukan bahwa literasi ekonomi siswa yang diterapkan dengan model pembelajaran group investigation meningkat. Dilihat dari hasil nilai posstest tersebut tentunya pada kelas eksperimen yang menjadi lebih baik dibandingkan dengan nilai posstest literasi ekonomi yang diterapkan dengan model pembelajaran konvensional (ceramah). Kelas eksprimen memperoleh nilai posstest sebesar 79,97, sedangkan nilai posstest pada kelas kontrol memperoleh nilai sebesar 69,47. Sehingga terjadi peningkatan antara kelas eksperimen dan kelas kontrol. Hal tersebut disebabkan setiap siswa memiliki kemampuan yang berbedabeda dalam memahami materi pembelajaran secara keseluruhan dan adapula yang sama sekali tidak bisa mengambil makna pembelajaran dari apaa yang telah dipelajari sehingga yang tercapai hanya sebatas mengetahui.

Menurut (Nasution, 2017) mengungkapkan bahwa adanya pengetahuan pembelajaran pada siswa yang berkualitas tinggi, hal ini dapat dihasilkan dari proses pembelajaran yang berkualitas baik, untuk dapat menghasilkan proses pembelajaran yang 
berkualitas baik seorang tenaga pendidik perlu membutuhkan kemampuan dalam menerapkan metode pembelajaran yang sesuai dan efektif dengan kebutuhan dalam kelas, ketidak sesuaian metode pembelajarapun yang diterapkan dapat menurunkan terhadap kualitas proses pembelajaran itu sendiri, dengan demikian maka perbaikan dan peningkatan pembelajaran siswa di sekolah dapat dilaksanakan dengan adanya penggunaan metode pembelajaran yangtepat oleh guru, dengan demikan dalam penelitian ini ingin mengetahui danmenganalisis mengenai penggunaan metode pembelajaran dalam peningkatan literasi ekonomi siswa di sekolah.

Dengan demikian peneliti mengemukakan keberhasilan pembelajaran ekonomi pada materi perkoperasian dalam perekonomian di indonesia dengan menggunakan model pembelajaran Group Investigation (GI) dilihat dari perilaku belajar siswa pada saat proses kegiatan pembelajaran siswa mampu bekerja sama dengan kelompok masing-masing untuk menginvestigasi dalam menyelesaikan masalah koperasi hal ini dilihat dari hasil kerja kelompok, pada saat pembelajaran siswa mendengarkan dan memperhatikan guru yang sedang menjelaskan materi, siswa lebih aktif dan berminat dalam mengikuti pembelajaran, dan siswa merasa perilaku disiplin secara individu maupun secara kelompok untuk mengumpulkan tugas secara baikdan tepat.

\section{Perbedaan Antara Literasi Ekonomi Siswa Yang Menerapkan Model Pembelajaran Group Investigation dengan Literasi Ekonomi Siswa Yang Menerapkan Model Pembelajaran Konvensional (Ceramah)}

Dengan adanya perbedan perlakuan yang diberikan terhadap kedua kelas tersebut nilai rata-rata dari literasi ekonomi siswa untuk kelas eksperimen sebesar 79,97. Sedangkan nilai rata-rata literasi ekonomi untuk kelas kontrol sebesar 69,47 dengan rentang nilai sebesar 10,5. Data yang diperoleh berdasarkan uji-t yang didapatkan dari nilai beda kelas eskperimen dan kelas kontrol dapat dilihat dari nilai $t$ hitung sebesar 4, 414. Sementara untuk mendapatkan nilai $\mathrm{t}_{\text {tabel }}$ dilihat pada uji $\mathrm{t}$ pada dua sisi dengan df yaitu 66 sebesar 1,997 , karena $t$ hitung $>t$ tabel $(4,414>1,997)$ sehingga $H_{o}$ di tolak dan $\mathrm{H}_{\mathrm{a}}$ di terima. Jadi dapat disimpulkan bahwa model pembelajaran Group Investigation dapat meningkatkan literasi ekonomi siswa pada mata pelajaran ekonomi kelas X di SMA Negeri 5 Kabupaten Tangerang.

Dengan demikian, karena literasi ekonomi yang diperoleh dengan perlakuan menggunakan model pembelajaran Group Investigation tinggi, maka perlakuan menggunakan model pembelajaran Group Investigation memberikan perbedaan signifikan yang baik dalam meningkatkan literasi ekonomi siswa. Group Investigation memberikan perbedaan signifikan yang baik dalam meningkatkan literasi ekonomi siswa, sehingga diharapkan kedepan tidak ada lagi siswa yang merasa bosan dan jenuh. Jadi diperoleh kesimpulan bahwa penerapan model pembelajaran Group Investigation dapat meningkatkan literasi ekonomi siswa secara signifikan dari pada menggunakan metode konvensional (ceramah).

\section{KESIMPULAN}

Dari s asil pembahasan yang telah dipaparkan dapat disimpulkan bahwa Literasi Ekonomi siswa yang menggunakan model pembelajaran Group Investigation sudah meningkat dibandingkan dengan literasi ekonomi siswa yang menggunakan model pembelajaran konvesional (ceramah). Peningkatan ini dapat dilihat pada nilai rata-rata pretest dan posttest kelas eksperimen dan kelas kontrol. Sehingga dapat dikatakan bahwa 
model pembelajaran Group Investigation dapat meningkatkan literasi ekonomi siswa kelas $X$ di SMA Negeri 5 Kabupaten Tangerang.

\section{REFERENSI}

Akhan, N. E. (2015). Economic Literacy Levels of Social Studies Teacher Candidates. World Journal of Education, 5(1). https://doi.org/10.5430/wje.v5n1p25

Amalia Di Girolamo, Glenn W. Harrison, M. I. L. and J. T. S. (2015). Subjective Belief Distributions and the Characterization of Economic Literacy. Durham University, 44(September), 1-12.

Ane Permatasari. (2015). membangun kualitas bangasa dengan buadaya literasi. 146-156.

Arikunto, S. (2017). Dasar-Dasar Evaluasi pendidikan. In Dasar-Dasar Evaluasi pendidikan (p. 79).

Astuti, Y. T., \& Agung Haryono. (2017). Implementasi Metode Brainstorming Dalam Model Group Investigation Pada Mata Pelajaran Ekonomi Untuk Meningkatkan Keaktifan Dan Hasil Belajar Siswa Kelas X Ips 3 Sman 1 Batu. Jurnal Pendidikan Ekonomi, 10(2), 109-117. https://doi.org/10.17977/um014v10i22017p109

Bayu permata, Hari Wahyono, dan C. W. (2016). Pengembangan bahan ajar berbasis cerita untuk menanamkan literasi ekonomi pada siswa sekolah dasar kabupaten situbondo. Ncee 2016, 1(ISBN: 978-602-17225-5-8), 55-67.

Chera Rizqi Faujiyah, Idad Suhada, S. H. (2017). Penerapan model pembelajaran. Jurnal Program Studi Pendidikan Biologi, 7(1), 1-72.

Cresswell, J. (2015). Riset Pendidikan perencanaan, pelaksanaan, dan evaluasi riset kualitatif\&kuantitatif.

Fauziyah, A (2017) Pengaruh Penggunaan Metode Pembelajaran Group Investigation Terhadap Literasi Keuangan Dengan Moderator Kecerdasan Emosional, Universitas Pendidikan Indonesia: Online, [http://repository.upi.edu/30124/ ]

Hambali, G. (2016). Literasi Ekonomi di Sekolah. 3(5), 42-52.

Haryono, A. (2013). Pengaruh Persepsi Proses Pembelajaran, Penilaian dan Status Sosial Ekonomi Terhadap Literasi Ekonomi Siswa SMA. Pendidikan Dan Pembelajaran, 20(2), 9-17.

Ibrahim. (2017). Perpaduan Model Pembelajaran Aktif Konvensional (ceramah) dengan coopertif (make-A match untuk meningkatkan hasil belajar pendidikan kewarganegaraan. 3(2), 199-212.

Iis aisyah. (2014). Pengaruh Pengalaman Belajar Dan Modernitas Terhadap Literasi Ekonomi. 1-8.

Indrawati, I. (2018). Pembelajaran Group Investigasi Meningkatkan Hasil Belajar Siswa. JEKPEND: Jurnal Ekonomi Dan Pendidikan, 1(1), 17. https://doi.org/10.26858/jekpend.v1i1.5056

kim et al. (2008). A multi-course collaborative project: Using technology to learn. Journal of Family and Consumer Sciences (p. 34). p. 34.

Kumalasari, D., \& Soesilo, Y. (2019). Pengaruh Literasi Keuangan, Modernitas Individu, Uang Saku Dan Kontrol Diri Terhadap Perilaku Konsumtif Mahasiswa Prodi S1 Pendidikan Ekonomi Angkatan Tahun 2016 Fakultas Ekonomi Universitas Negeri Malang. Jurnal Pendidikan Ekonomi, 12(1), 61-71.

Lilik Ernawati. (2017). Pengaruh Status Sosial Ekonomi Orangtua dan Hasil Belajar Ekonomi Terhadap Literasi Ekonomi di SMP Negeri 43 Surabaya. Jurnal Ekonomi Pendidikan Dan Kewirausahaan, 5(2), 230-245. 
Lukito, R. (n.d.). Menakar Literasi Kita, media indonesia.

Martaida, T. dkk. (2017). The Effect of Discovery Learning Model on Student's Critical Thinking and Cognitive Ability in Junior High School. Iosr-Jrme, 7(6), 1-8. https://doi.org/10.9790/7388-0706010108

Mathews, L. G. (1999). Promoting Economic Literacy: Ideas for Your Classroom.

Matroji. (2015). Penerapan Model Group Investigation Untuk Meningkatkan Hasil Belajar Siswa Dalam Pembelajaran Sejarah Materi Pengaruh Sejarah Dunia Terhadap Sejarah Bangsa Indonesia Abad 18-20 (Ptk Pada Kelas Ix Ips Semester Genap Di Sma Negeri 1 Tambun Utara Tahun. Pegagogia : Jurnal Ilmu Pendidikan, 356-362.

Muhammad Andri Utama; Dwi Atmono, S. (2016). Perbandingan literasi ekonomi antara siswa yang berasal dari sekolah swasta di banjarmasin. Jurnal Pendidikan Ekonomi, Vol.4 No.1.

Nasution, M. K. (2017). Penggunaan Metode Pembelajaran Dalam Peningkatan Hasil Belajar Siswa. Jurnal Ilmiah Bidang Pendidikan, 11(1), 9-16.

Nur, A. (2014). Model Pembelajaran Group Investigation ( Gi ) Dilengkapi Media Peta Pikiran Pada Materi Pokok Kelarutan Kelas Xi Ipa Sma Negeri Kebakkramat. Jurnal Pendidikan Kimia (JPK), 3(2), 1-6.

Nurul Lailiya, S. (2019). Pengaruh status sosial ekonomi rumah tangga danliterasi ekonomi terhadap perilaku konsumtif siswa. Pendidikan Ekonomi, 12(1), 1-9.

PISA. (2012). PISA 2012 Results in Focus. Programme for International Student Assessment, 1-44. https://doi.org/10.1787/9789264208070-en

R. M. Gillies A. F. Ashman J. Terwel. (2008). The Teacher's Role in Implementing Cooperative Learning in the Classroom.

Reber, M. F. (2010). Systems thinking for an economically literate society. Libertarian Papers., 2(33), 1-14.

Saepuloh, D. (n.d.). Analisis prestasi belajar siswa pelajaran ekonomi, status sosial ekonomi orang tua dan bimbingan belajar. (2), 46-62. Retrieved from http://ejournal.unis.ac.id/index.php/perspektif/article/view/77

Sai, M. (2017). Pengaruh model group investigation berbasis internet terhadap hasil belajar dan kemampuan digital literasi siswa. Harmoni Sosial: Jurnal Pendidikan IPS, 4(1), 39. https://doi.org/10.21831/hsjpi.v4i1.9869

Sharan, Y., \& Sharan, S. (1990). Group investigation expands coopetaive learning. (December 1989).

Sumanik Magdalena. (2015). Penggunaan Model Pembelajaran Group Investigation Untuk Mencapai Kompetensi Belajar Biologi Materi Sistem Peredaran Darah Manusia Pada Siswa Kelas VIII SMP St . THERESIA. 1, 179-187.

Takaeb, M. J., \& Mone, F. (2018). Pengaruh model pembelajaran cooperative tipe group investigation berbantuan media gambar terhadap prestasi belajar siswa kelas VIII SMP NEGERI 3 Soe. 1(2), 33-38.

Tharenou, P., Donohue, R., \&. C. (2017). Experimental and quasi-experimental designs (pp. 33-44).pp. 33-44.

Utomo, E. P. (2018). Pengembangan LKPD berbasis komik untuk meningkatkan literasi ekonomi peserta didik. Jurnal Penelitian Pendidikan, 35, 1-10.

41 | Jurnal Pendidikan Eknnomi, Vol.I3, No.I, 2020, Hal. 30-4| 